\title{
DYNAMICS AND STRUCTURE OF GRIESGLETSGHER, SWITZERLAND
}

\author{
By M. J. Hambrey, \\ (Department of Geology, Sedgwick Museum, Cambridge CB2 3 EQ, England)
}

A. G. Milnes,
(Geologisches Institut, Eidg. Technische Hochschule-Zentrum, CH-8og2 Zürich, Switzerland)

and $\mathrm{H}$. Siegenthaler

(Versuchsanstalt für Wasserbau, Hydrologie und Glaziologie, Eidg. Technische HochschuleZentrum, CH-8og2 Zürich, Switzerland)

Abstract. A detailed investigation has been carried out on the dynamics of an Alpine valley glacier of relatively simple shape and the results are considered in relation to the development of secondary structures. Ice velocity reaches a maximum near the top of a small ice fall $\left(40 \mathrm{~m} \mathrm{a}^{-1}\right)$ which also coincides approximately with the equilibrium line. Flow lines converge in the accumulation area but are roughly parallel in the ablation area. The "regional" strain-rate pattern is rather complex. Approximate longitudinal extension is evident in the accumulation area and strain-rates reach high values at the south margin and in the ice fall (up to $0.12 \mathrm{a}^{-1}$ ). In the ablation area, strain-rates are comparatively small and in general indicate longitudinal compression. "Local" deformation rates obtained in the area beneath the ice fall and along a flow line near one of the margins reveal complex patterns of deformation within small areas.

There is no clear relationship between foliation and strain-rates (and by analogy stresses), except in the case of longitudinal foliation in marginal areas which, if actively developing, lies approximately parallel to a direction of maximum shear strain-rate. It is more important to consider the relationship of this structure to strain history. Results from this study indicate that, regardless of the initial orientation of the foliation in relation to the strain ellipse, it attains approximate parallelism with the long axis of the ellipse as deformation progresses.

It is also shown that many foliations originate from pre-existing layered structures such as stratification or crevasse traces. This problem is discussed particularly with reference to an arcuate foliation which originates in the ice fall and is believed to represent tensional veins, subsequently subjected to compressive strain within and below the ice fall.

RÉsumé. Dynamique et structure du glacier de Gries en Suisse. Une étude approfondie a été effectuée sur la dynamique d'un glacier de vallée alpin de forme relativement simple et les résultats sont considérés en rapport avec le développement de structures secondaires. La vitesse de la glace atteint son maximum $\left(40 \mathrm{~m} \mathrm{a}^{-1}\right)$ au voisinage d'une petite chute qui coïncide approximativement avec la linge d'équilibre. Les lignes de courant convergent dans la zone d'accumulation, mais demeurent en revanche à peu près parallèles dans la zone d'ablation. La distribution "régionale" des vitesses de déformation est assez complexe. Les déformations de traction plus ou moins longitudinales sont évidentes dans la zone d'accumulation et les vitesses de déformation atteignent des valeurs élevées sur la rive sud et dans la chute du glacier (jusqu'à $\left.\mathrm{o}, 12 \mathrm{a}^{-1}\right)$. Dans la zone d'ablation, les vitesses de déformation sont comparativement faibles et indiquent en général une compression longitudinale. Les vitesses de déformation "locales" observées dans la zone située au-dessous de la chute du glacier, de même que le long d'une ligne de courant proche de l'une des rives, révèlent une répartition complexe des déformations à l'intérieur de zones d'étendue restreinte.

Il n'y a pas de rapport évident entre la foliation (texture feuilletée du glacier) et les vitesses de déformation (et, partant, les contraintes), sauf dans le cas de la foliation longitudinale observée dans les zones latérales, laquelle, lorsqu'elle se trouve en état de développement actif, coïncide approximativement avec la direction des déformations de cisaillement maximales. Il est plus important de considérer la relation existant entre cette structure et l'histoire du fluage; les résultats de cette étude montrent que, quelle que soit l'orientation initiale de la foliation par rapport à l'ellipse des vitesses de déformation, celle-ci devient approximativement parallèle au grand axe de l'ellipse lors de la progression du fluage.

On montre également que de nombreuses foliations ont pour origine des structures déjà stratifiées telles que des traces de crevasses et ce problème est traité spécialement en rapport avec la foliation arquée qui prend naissance dans la chute du glacier et que l'on considère être la manifestation de veines de tension qui ont par la suite été soumises au fluage compressif à l'intérieur et au-dessous de la chute du glacier.

Zusammenfassung. Dynamik und Struktur des Griesgletschers, Schweiz. Eine eingehende Untersuchung über die Bewegungsverhältnisse eines alpinen Talgletschers von relativ einfacher Form wurde durchgeführt; die Ergebnisse werden in Beziehung zur Entwicklung sekundärer Strukturen gesetzt. Das Maximum der Eisgeschwindigkeit $\left(40 \mathrm{~m} \mathrm{a}^{-1}\right)$ tritt im oberen Teil einer Steilstufe auf, wo auch ungefähr die Gleichgewichtslinie verläuft. Im Akkumulationsgebiet konvergieren die Fliesslinien, im Ablationsgebiet laufen sie ungefähr 
parallel. Die "regionale" Verformungsbildung ist ziemlich komplex. Im Akkumulationsgebiet zeigt sich longitudinale Dehnung, und die Deformationsgeschwindigkeiten erreichten am südlichen Gletscherrand und in der Steilstufe hohe Werte (bis zu o, 12 pro Jahr). Im Ablationsgebiet sind die Deformationsgeschwindigkeiten verhältnismässig klein und weisen im allgemeinen auf longitudinale Kompression hin. "Lokale" Deformationsgeschwindigkeiten, die im Gebiet unterhalb der Steilstufe und entlang einer Fliesslinie in Nähe des Gletscherrandes gemessen wurden, lassen komplexe Deformationsmuster innerhalb kleiner Gebiete erkennen.

Es zeigt sich kein klarer Zusammenhang zwischen Bänderung und Deformationsgeschwindigkeiten (und analog Spannungen), ausser im Fall von longitudinaler Bänderung in randlichen Zonen, welche im Entstehungsgebiet annähernd parallel zu einer Richtung maximaler Scherungsgeschwindigkeit liegt. Es ist wichtiger, das Verhältnis dieses Strukturelementes zur Verformungsgeschichte zu betrachten. Die Ergebnisse dieser Studie zeigen, dass sich die Schieferung ungeachtet ihrer Anfangsorientierung zur Verformungsellipse, mit fortschreitender Deformation ungefähr parallel zur längeren Ellipsenachse stellt.

Im weiteren zeigt sich, dass viele Bänderungen aus vorgegeben Strukturen wie etwa der Schichtung oder den Spuren von Spalten stammen. Dieses Problem wird besonders diskutiert im Hinblick auf eine bogenförmige Bänderung, die aus der Steilstufe stammt und von der angenommen wird, dass sie Zugklüfte darstellt, welche nachträglich innerhalb und unterhalb der Steilstufe einer Kompression unterworfen wurden.

\section{INTRODUGTION}

The purpose of this paper is to present the results of an extensive analysis of the surface dynamics of a temperate Alpine valley glacier, and to discuss their relationship to secondary structures, in particular foliations. The glacier, Griesgletscher near Nufenenpass (canton of Valais, Switzerland; see Figure ra), has already been described in detail from the point of view of structures and cumulative strains (Hambrey, 1977; Hambrey and Milnes, 1977), so these aspects are only touched on briefly here.

The $5 \mathrm{~km}$ long and $0.6-1.5 \mathrm{~km}$ wide glacier rises on the peak of Blinnenhorn $(3374 \mathrm{~m})$ and terminates as a cliff in the recently impounded lake of Griessee, which when full has a surface level of $2386 \mathrm{~m}$ (see figure $\mathrm{I}$ in Hambrey (1977)). Since the construction of the dam, the glacier has retreated considerably, principally by calving into the lake. The main mass of ice flows around a gentle curve in the neighbourhood of a small ice fall near the equilibrium line (at c. $2876 \mathrm{~m}$; personal communication from R. J. Braithwaite, 1978). The northern boundary of this flow unit is delimited by a sub-ice rock ridge (recently exposed in one small area), to the north of which is a distinct ice-filled east-facing trough.

Before the start of the present project, much velocity data had been accumulated in connection with a mass-balance study carried out for the hydro company Kraftwerke Aegina AG. Data for the balance year $1972-73$ form the basis of the present study, as this was when the network of markers was most extensive (Fig. Ia). As a result, a unique picture of the dynamics of a whole glacier has been obtained. Certain areas were selected for more detailed strain analysis to obtain a better understanding of the development of foliations; strain networks were established between 1975 and 1976 at the foot of the ice fall and along a flow line near the southern margin.

Structurally, the glacier is complex (Hambrey and Milnes, 1977). Three foliations develop successively as the ice moves down-hill; they are defined by variations in bubble content and grain-size, and occasionally by distinct planar surfaces. An early longitudinal foliation, isoclinally folded on a large scale, has been subjected to minor folding within the region of the ice fall, while concurrently a new vertical arcuate foliation develops in axial planar relationship to the minor folds. Down-glacier the folds become tighter, especially at the margins, where rotation and deformation also bring all structures into a longitudinal orientation. The dip at the apices of the arcs declines down-glacier, while the longitudinal foliation remains vertical. A weak, third longitudinal foliation develops in the centre of the glacier about $1.5 \mathrm{~km}$ from the snout. Some aspects of the distribution and degree of development of these structures, and their relationships to cumulative strains are illustrated in Figure 2. Other structures, notably stratification, crevasse traces, boudins, "mylonite" zones, and debris-rich layers also occur (Hambrey and Milnes, 1977). 

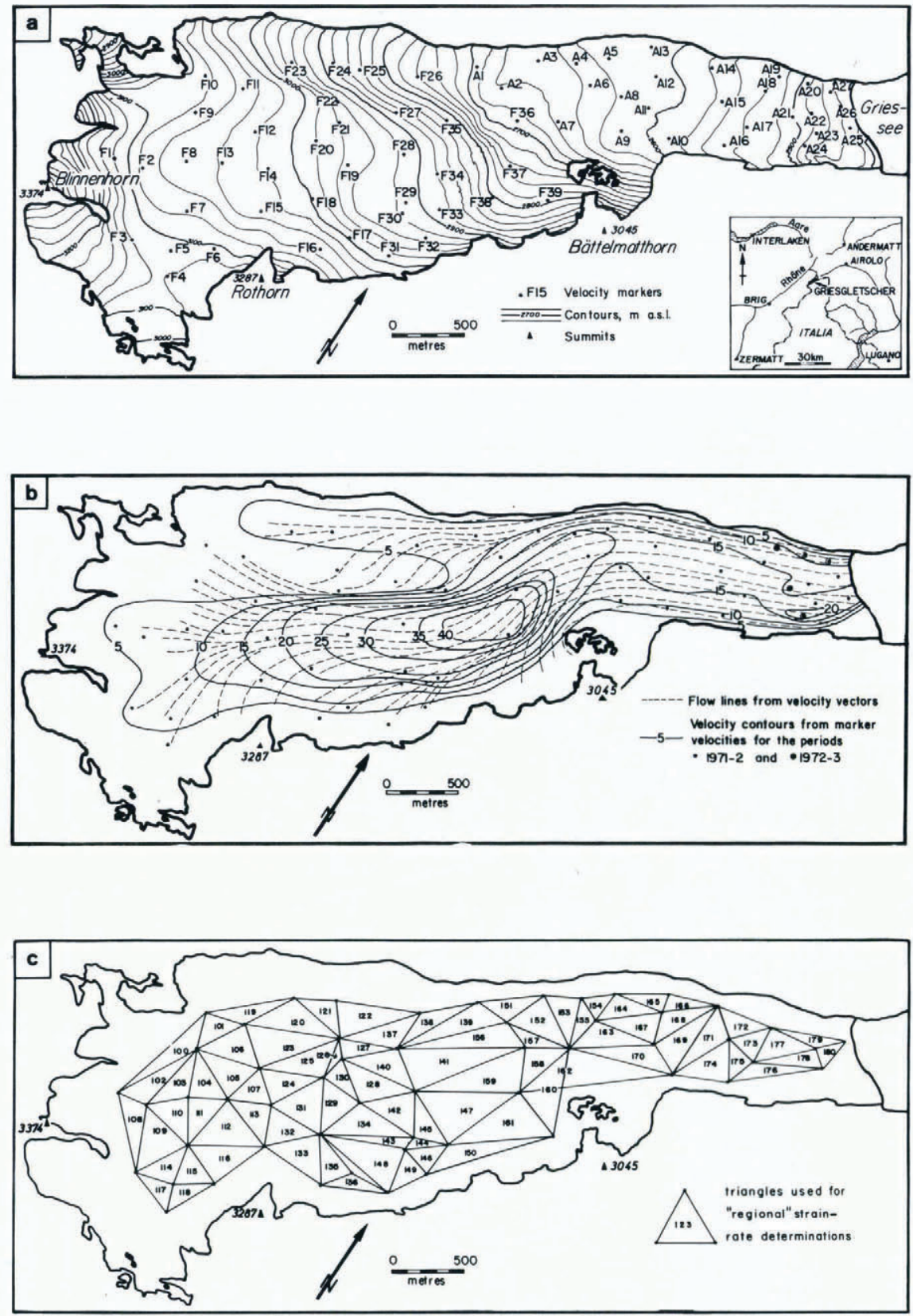

Fig. I. (a) Contour and location maps of Griesgletscher with positions of stakes; $F$ indicates stakes in firn, $A$ stakes in the normal ablation area. (b) Distribution of surface velocity, $1972-73$, with additional data from $1971-72$. (c) Numbering of strain triangles. The ice fall occurs in the neighbourhood of stakes $F_{35}$ and $F_{37}$. 


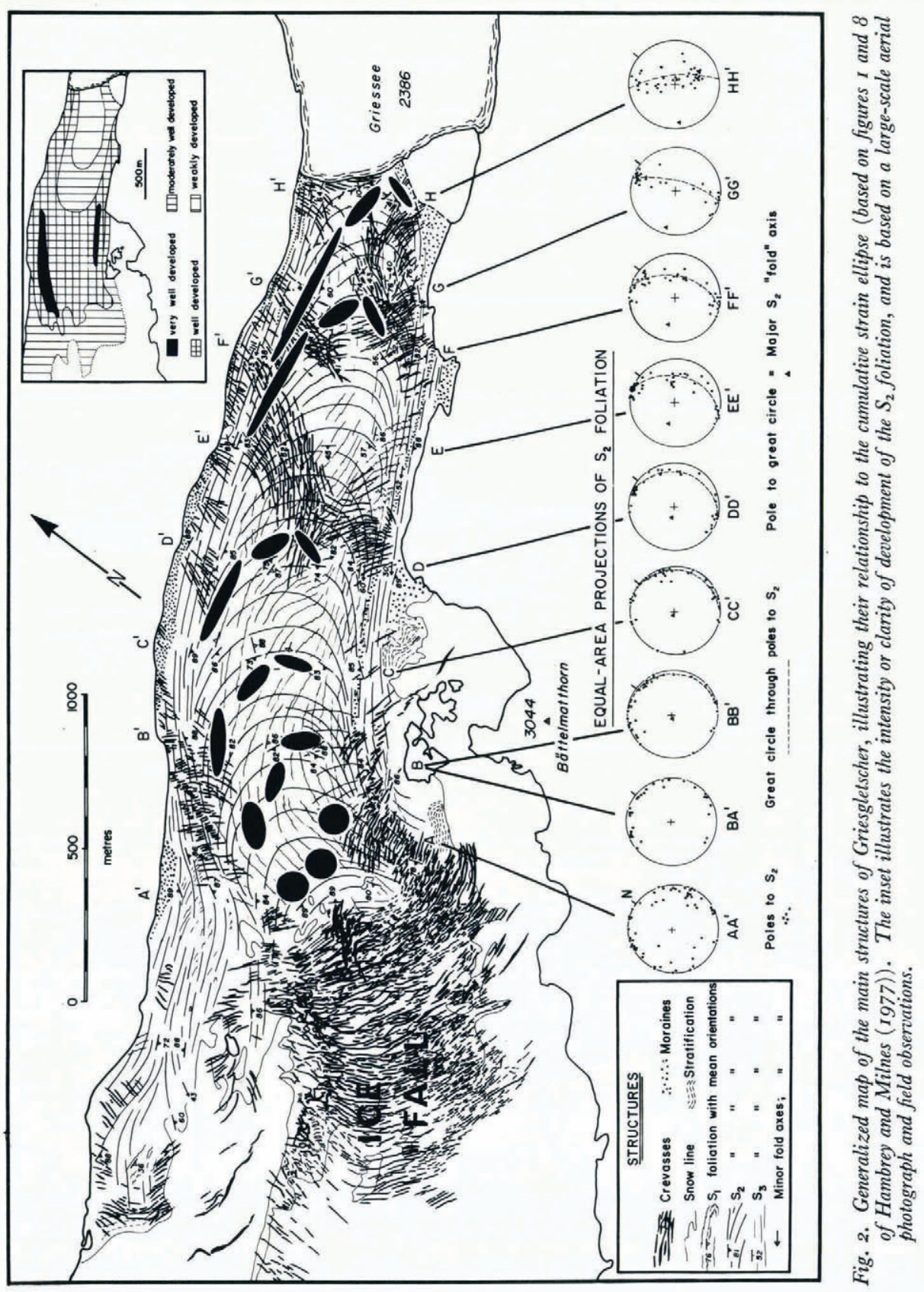




\section{Dynamics of Griesgletscher}

\section{Velocity distribution}

The velocities of numerous stakes, surveyed from fixed points on bedrock, have been determined annually since $\mathrm{I} 96 \mathrm{I}$. The most extensive network of stakes existed in the period 1972-73, and the data from these years, supplemented by data from 1971-72, have been used as a basis for the present study. From the rates and directions of movements of the stakes, a velocity distribution and flow-line map has been constructed (Fig. Ib). Annual variations in velocity noted by comparing the 1972-73 figures with those of earlier years, tend to be greatest in marginal areas. These not only reflect the movements of individual stakes into areas of different velocity but also changes in velocity at a single location. For example, many stakes in marginal areas one year may show a consistent increase in velocity over the previous year, followed by a decrease the following year; this characteristic may be a function of variations in the availability of melt water in summer time.

In the accumulation area, the flow lines tend to converge and the velocity increases to a maximum of over $40 \mathrm{~m} \mathrm{a}^{-1}$ near the mean equilibrium line at the top of the ice fall. Within and below the ice fall the velocity decreases rapidly to about $25 \mathrm{~m} \mathrm{a}^{-1}$. Thereafter the decrease is slow and ice at the centre of the glacier still flows at more than $15 \mathrm{~m} \mathrm{a}^{-1}$ at the terminal cliff. The ice in the east-facing trough at the north side of the accumulation area acts as a separate, slowly moving flow unit which, as the structures indicate, is almost entirely pinched out below the ice fall. No stakes were inserted to record ice movement at the extreme edges of the glacier, but there is little field evidence of pronounced marginal slipping, except past one or two minor spurs at the north side of the glacier.

\section{Determination of deformation rates}

Procedure. Strain-rates were determined for most of the surface of the glacier using velocity data obtained during the balance year $1972-73$ by calculating the changes in length of the sides of triangles defined by velocity stakes. (For fuller details of the method used, see Hambrey and Müller (1978, p. 5I ).) These strain-rate data assume homogeneous strain over wide areas, sometimes several hundreds of metres across, and are referred to as "regional" strain-rates.

As structural relations clearly indicate that strain is not homogeneous over such wide areas, more localized deformation rates were obtained between 1975 and 1976 in areas of special interest, namely along a more-or-less complete transverse profile at the foot of the ice fall, and at various points along a flow line (deliminated by a small medial moraine) near the south margin of the glacier. These are referred to as "local" strain-rates. Roughly equilateral arrays of stakes were used to determine the local strain-rates. The stakes were inserted approximately $20-50 \mathrm{~m}$ apart and the distances between them measured with a $50 \mathrm{~m}$ steel tape under a standard tension of $2.5 \mathrm{~kg}$. To overcome problems of sag and changes in the length of the tape according to temperature variations, the inter-stake distances were measured when the stakes were flush with the glacier surface, i.e. initially when the stakes were first inserted into the ice, and in the second year when they were first exposed as the intervening winter snow-pack ablated. Stretching the tape across the ice or snow surface also ensured an even temperature close to $0^{\circ} \mathrm{C}$. To minimize errors, distances were measured at least three times to an accuracy of $\mathrm{I} \mathrm{cm}$ and the mean values taken, while the orientations of one of the sides were measured using a "Silva ${ }_{5} \mathrm{~T}$ " compass. Exact fixing of the stake arrays was possible by referring to the surveyed stakes in the mass-balance network and other features of known position. Strain-rates parallel to the surface were determined in the same way as the larger triangles. The accuracy of the principal strain-rates is generally better than $\pm 0.007 \mathrm{a}^{-1}$ in magnitude and two degrees in orientation, the greatest errors arising from the difficulty of measuring precisely between stakes standing in water-filled holes. With the data available, 
the accuracy of the regional principal strain-rates could not be determined precisely. Here, any error is likely to have arisen from surveying inconsistencies, and, as the stakes were fixed to the nearest centimetre from permanent bedrock stations, the accuracy in strain-rates is almost certainly considerably better than $\pm 0.005 \mathrm{a}^{-1}$.

Regional strain-rate pattern. The regional strain-rate pattern is rather complex (Fig. 3) and probably reflects the irregularities of the channel geometry. In the upper part of the accumulation area, the principal strain-rates $\dot{\epsilon}_{\mathrm{I}}$ (greatest) and $\dot{\epsilon}_{2}$ (least) are small (see Figure Ic for key to locations). The values increase irregularly but markedly towards the equilibrium line
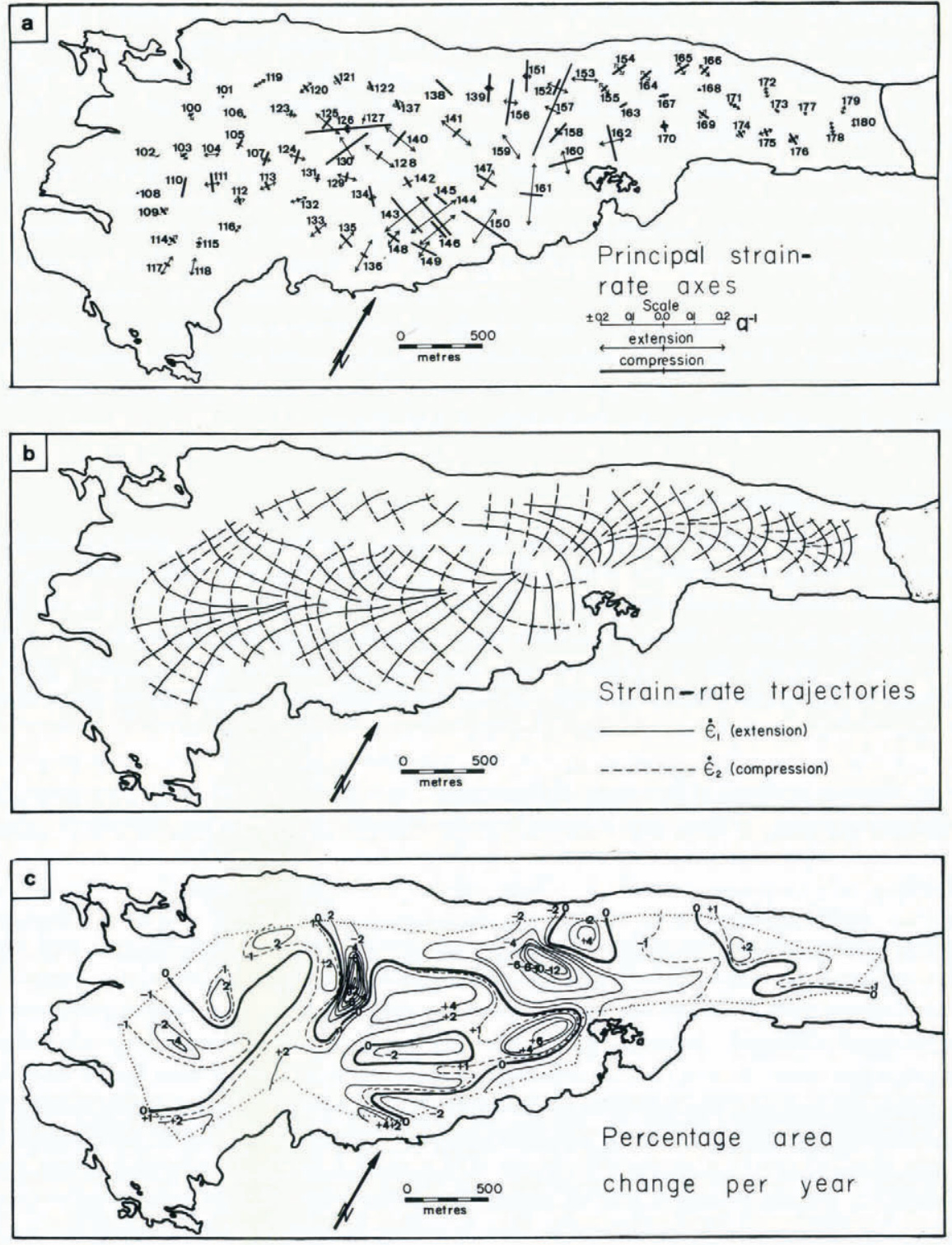

Fig. 3. (a) Principal strain-rates at the surface of Griesgletscher, 1972-73. (b) Trajectories of maximum and minimum principal strain-rates. (c) Percentage changes in surface area per year. 
and the top of the ice fall. Much of the deformation is in the form of marginal shear at the south side of the glacier where principal regional strain-rates up to $\pm 0.09 \mathrm{a}^{-1}$ are apparent; by contrast, deformation at the northern boundary of the main part of the glacier, adjacent to the sub-ice rock ridge, is comparatively small. Extension in an approximately longitudinal direction characterizes the orientation of the principal strain-rates in the accumulation area, the principal extension axes tending to lie at small angles to the flow lines (cf. Figure 3 a with Figure $\mathrm{I} b$ ).

In the ice fall, the large size of the strain triangles results in a grossly oversimplified picture of the strain-rate pattern. All that can be noted is that, at the top of the ice fall, $\dot{\epsilon}_{\mathrm{I}}$ is parallel to the flow direction and attains values of at least $0.10 \mathrm{a}^{-1}$, while at the bottom $\dot{\epsilon}_{2}$ is parallel to the flow and reaches values of at least $0.16 \mathrm{a}^{-1}$.

In the tongue of the glacier the strain-rate pattern is broadly similar to that observed in the ablation areas of other glaciers, such as Saskatchewan Glacier (Meier, r 96o), Blue Glacier (Meier and others, I974) and White Glacier (Hambrey and Müller, I978). However, the magnitudes of the principal strain-rates are small compared with those at other glaciers and also in the higher parts of Griesgletscher (Fig. 3).

A clearer view of the strain-rate pattern is obtained by drawing trajectories of $\dot{\epsilon}_{1}$ and $\dot{\epsilon}_{2}$ (Fig. 3b). On the basis of these, the main part of the glacier is seen to consist of two distinct deformation fields. An upper field, above the ice fall, has trajectories of $\dot{\epsilon}_{\mathrm{I}}$ which tend to be longitudinal and to converge down-glacier, with $\dot{\epsilon}_{2}$ forming concave down-glacier arcs. A lower field, coincident with the ablation area, illustrates $\dot{\epsilon}_{\mathrm{I}}$ trajectories with convex downglacier arcs and $\dot{\epsilon}_{2}$ trajectories which diverge strongly. An additional field with a distinct pattern coincides with the slowly moving ice in the east-facing trough at the north side of the accumulation area.
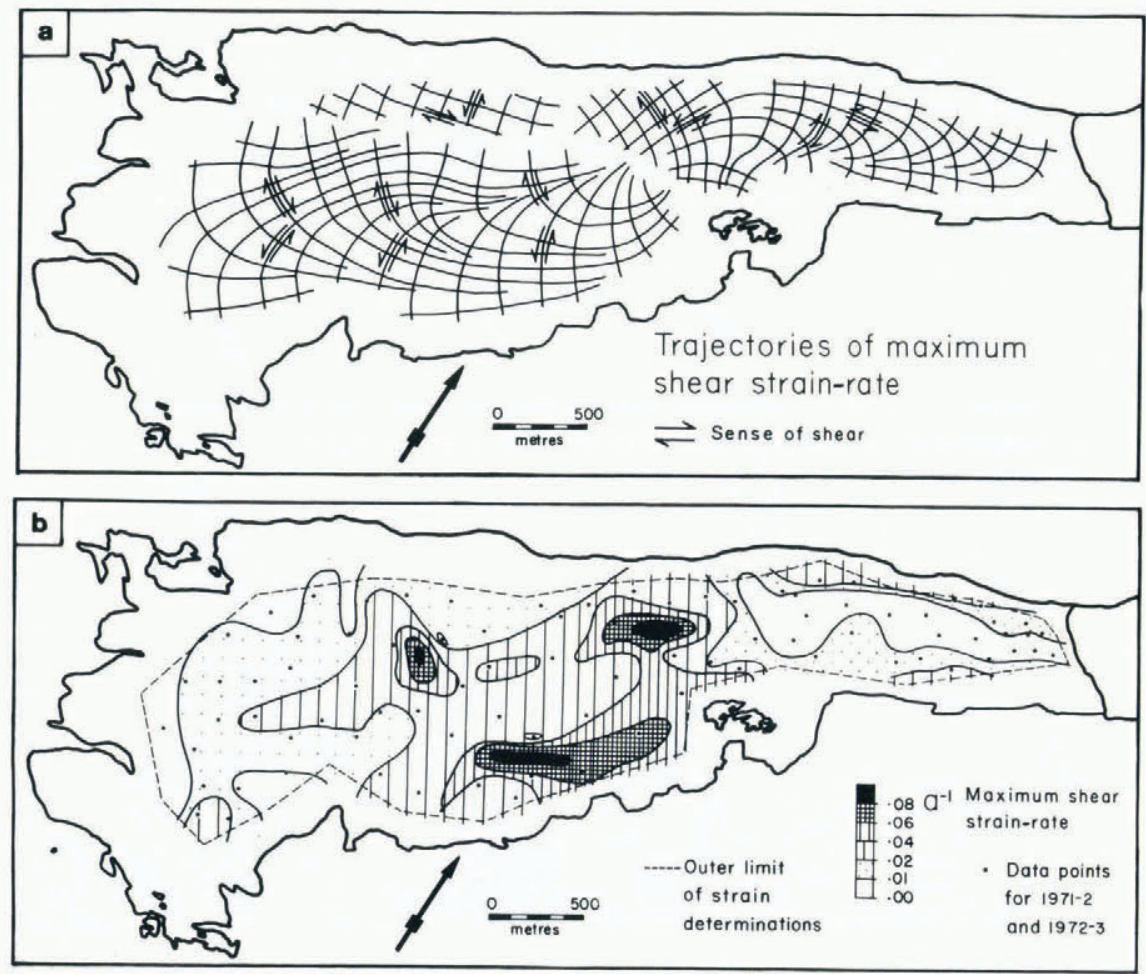

Fig. 4. (a) Trajectories and sense of maximum shear strain-rate. (b) Magnitude of maximum shear strain-rate. 
Surface deformation rates can also be expressed in terms of percentage areal changes per year. It is clear from Figure $3 \mathrm{c}$ that the greatest areal changes occur in the middle and lower parts of the accumulation area and within the ice fall. Two main zones of decrease in surface area, which implies thickening of the glacier, occur. One, in part of the north side of the accumulation area, is difficult to explain; the other, as expected, occurs near the foot of the ice fall where the surface slope is concave. Maximum areal increase, representing thinning of the glacier, occurs to the south side of the top of the ice fall where the slope is convex. Areal changes throughout the tongue are very small when considered on this regional scale.

Maximum shear strain-rates obtained from the principal strain-rate data are summarized in Figure 4. The highest values of maximum shear strain-rate (over $0.08 \mathrm{a}^{-1}$ ) occur near the margins of the main part of the glacier in the middle zone of the accumulation area, with a further peak in the ice fall. Low values occur in the upper part of the accumulation area, while in the central part of the tongue there is practically no regional shear strain (Fig. 4 b). The trajectories of maximum shear strain-rates form a fairly complex pattern but it is noticeable that in the marginal areas of much of the glacier they tend to be approximately normal and parallel to the valley sides, as one might expect (Fig. 4a).

Local deformation rates on a transverse profile. Forty triangular strain nets, deliminated by 42 stakes, were established on an almost complete transverse profile at the foot and on either side of the ice fall (Fig. 5a). The north-west end of the profile lies in the subsidiary slow-moving flow unit occupying the east-facing trough at the north of the accumulation area, while the south-east end falls in a very heavily crevassed region to the east of the main part of the ice fall.
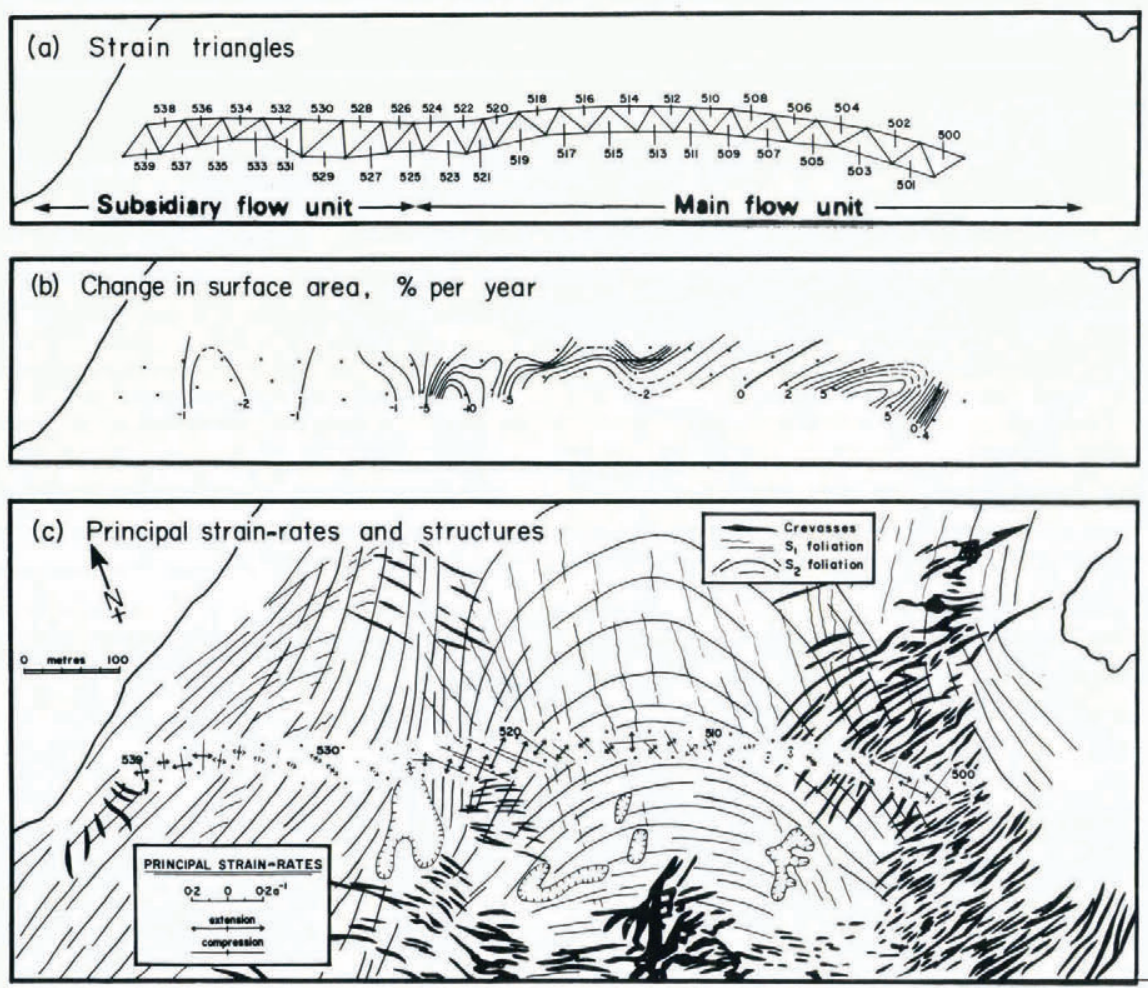

Fig. 5. Local strain-rate measurements at the foot of the ice fall. (a) Key to strain triangles. (b) Percentage change in surface area per year. (c) Principal strain-rate axes and their relation to foliation. 
The principal local strain-rates vary greatly, both in magnitude and orientation (Fig. $5 \mathrm{c}$ ), reflecting the complexity of flow in this region. The principal strain-rates and shear strainrates in the subsidiary flow unit (Fig. 5; triangles 539-527) show a regular change in orientation which resembles that of complete cross-sections in other valley glaciers undergoing longitudinal compression (e.g. Meier, I96o; Meier and others, I974; Hambrey and Müller, 1978). Near the north-west margin of the main flow unit, the principal strain-rates increase strongly, giving maximum values of $\dot{\epsilon}_{\mathrm{I}}=0.10$ and $\dot{\epsilon}_{2}=-0.18 \mathrm{a}^{-1}$ (triangles $522-519$ ). This area also has the highest shear strain-rates recorded (o.14). Thereafter, an irregular decrease to values of less than $\pm 0.01 \mathrm{a}^{-1}$ is evident, followed by a further marked increase to $\dot{\epsilon}_{\mathrm{I}}=0.14$ and $\dot{\epsilon}_{2}=-0.12$ in the heavily crevassed zone at the end of the profile (502-500). Local areal changes in the subsidiary flow unit are small, while those in the main part of the glacier range from strongly negative $\left(-12 \% \mathrm{a}^{-1}\right)$ at the left-hand side of the ice fall to strongly positive $\left(+9 \% \mathrm{a}^{-1}\right)$ in the strongly crevassed region at the south-eastern end of the profile (Fig. 5b).

Local deformation rates on a longitudinal profile. Five additional triangular strain nets were established astride a weakly developed medial moraine in an attempt to determine how the structural pattern changes in relation to progressive deformation in a mass of ice as it moves down-stream (Fig. 6). Included in this series is triangle 50 I of the transverse profile. The principal strain-rates are variable but all are of moderately high magnitude as one would expect near the margin of a glacier. These values range from \pm 0.04 to $\pm 0.13 \mathrm{a}^{-1}$, while the shear strain-rates range from 0.5 to $0.9 \mathrm{a}^{-1}(50 \mathrm{I}, 404-400)$. The principal extensions at the upper two sites, where crevasses are well developed nearby, are orientated at higher angles to the flow line $\left(40-60^{\circ}\right)$ than are those at the sites lower down. A corollary of this is that the maximum shear strain-rate is orientated approximately parallel to the margin only at the lower sites. Surface areal changes along this profile, except at triangle 50 , are negative, small in the lower part and large at triangle 404 .

Cumulative strains. Most studies of deformation in glaciers have considered only strain-rates which, in a geological sense, can be regarded as small increments of strain. In terms of the development of structures such as foliations and folds, it is important to consider not only successive increments (which at any time may be fortuitous with regard to structural development), but also the sum total of these increments, i.e. the cumulative or finite strains.

Approximate bulk cumulative strains were determined for that part of Griesgletscher lying below the ice fall with a view to establishing their relationship with foliations and other structures. By tracing semi-graphically the changes of shape of arbitrarily drawn triangles on a flow-line and velocity-contour map, it is possible to determine strain ellipses for different time intervals (e.g. 5o, I oo years) (see Milnes and Hambrey (1976) for a full description of the method and assumptions made). The full results have been reported elsewhere (Hambrey and Milnes, 1977); they are briefly summarized here for completeness. These strains are greatest near the margins of the glacier, as indicated by the deformation of circles into ellipses. The strain ellipses initially are orientated with their long axes at an angle to the flow direction and to the margins, but are rotated towards parallelism with the flow lines, rapidly at first then more slowly, as they are traced down-glacier (Fig. 2). In the centre of the glacier the horizontal cumulative strain increases rapidly immediately below the ice fall but then undergoes only slight changes in axial ratio and orientation towards the snout (Fig. 2). This indicates that the strain is approximately coaxial in the centre of the glacier but non-coaxial at the margins. It is evident from these results that, whether or not the foliation initially lies parallel to the long axis of the cumulative strain ellipse, the tendency is for approximate parallelism to occur eventually (cf. Hambrey and Milnes, I977). 


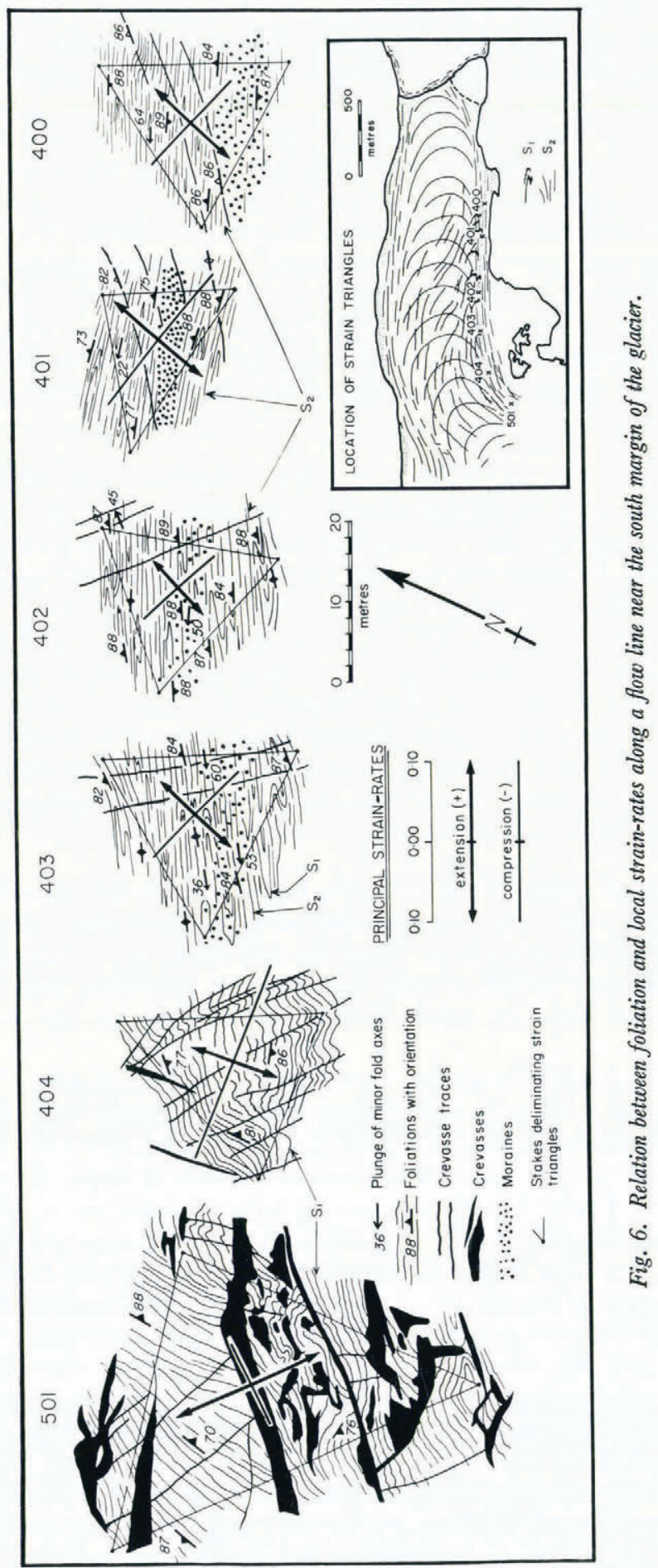




\section{Discussion}

Several attempts have been made to relate foliations to the stress distribution in glaciers, using the principle of direct analogy between the stress and the (measured) strain-rate tensors. Some authors have suggested, for example, that longitudinal foliation is the result of shear (e.g. Allen and others, I960; Anderton, 1973), but measurements by Meier (1960), Anderton (1973), and Hambrey and Müller (r978) have indicated that foliation need not necessarily develop parallel to a direction of maximum shear strain-rate (and by analogy maximum shear stress). In general, one can say that these comparisons have only indicated that there is no simple relationship applicable to all glaciers. The present study, which is much more extensive than earlier ones, emphasizes this point. On the basis of earlier studies on other glaciers, arcuate foliation is expected to develop in a zone at the foot of the ice fall. On Griesgletscher, at the base of the ice fall, this structure lies at many orientations with respect to the principal stress (strain-rate) axes. The only evidence for any geometric relationship between foliation and stress occurs near the right-hand margin away from the influence of any crevasses, where longitudinal foliation tends to lie parallel to a line of maximum shear stress. Data from other glaciers indicate that this relationship holds only where this foliation is the active structural element (Hambrey and Müller, i978, fig. II).

It is clear from the present study that to try and relate some foliations to the stress distribution is a rather pointless exercise. Whilst in certain cases one might establish that marginal longitudinal foliation, if actively developing, is orientated parallel to a direction of maximum shear stress, no relationship between stress and other foliation types is to be expected. Foliations reflect the strain history rather than a possibly fortuitous strain increment measured at a particular point or time, and it is more profitable to analyse the problem in terms of cumulative strains, the importance of which have only been fully appreciated in the last few years (see Hooke and Hudleston, 1978). Our Griesgletscher cumulative strain results (Hambrey and Milnes, 1977) have illustrated the validity of this approach and have yielded information that is more relevant to an understanding of the development of glacier structure. We have shown that, whether or not foliations are initially normal to the compressive stress or parallel to a direction of maximum shear stress, or somewhere in between, the final relationship is one of approximate parallelism between the foliation and the long axis of the cumulative strain ellipse. In the general case of non-coaxial deformation paths, the latter is unrelated to the current stress conditions. A similar parallelism between the long axis of the cumulative strain ellipse and foliation has been inferred by Hooke and Hudleston (I 978).

It becomes apparent why strain-rates often have little bearing on structural development when we consider the origin of these structures. Although not widely recognized, it has been established that in certain cases foliations result from the transposition or modification of other types of layering, such as stratification (e.g. Hambrey, i 976) or crevasse traces (Hambrey and Milnes, 1977). Such an origin of foliation has recently been emphasized by Hooke and Hudleston (1978). These authors believed that the variations in bubble and dirt content, which often define foliation, are generally inherited from primary inhomogeneities, such as stratification, crevasse fillings, or during debris entrainment at the base of the glacier. It is these inhomogeneities which are subsequently modified by strain during flow to produce foliation. The importance of this problem is highlighted when one considers the origin of arcuate foliation, a structure that occurs in many glaciers. Arcuate foliation generally originates in or below ice falls (e.g. Schwarzacher and Untersteiner, 1953; Allen and others, 1960; Gunn, 1964; Rutter, 1965; Ragan, 1969), or in areas of extensive transverse crevassing. An early hypothesis concerning its development based on observations on lower Blue Glacier, Washington, was that the structure forms in a vertical transverse attitude as a result of longitudinal compression at the foot of the ice fall, followed by passive behaviour during subsequent flow (Allen and others, r960). Ragan ( 1969 ) pointed out a number of difficulties with this 
interpretation; he considered that an initially vertical transverse attitude of foliation was unacceptable, because the developing foliation then would be inclined down-stream relative to the slope and to the principal compressive stress; instead such a structure should form perpendicular to the slope. Ragan examined the structures below the ice fall of Gulkana Glacier, Alaska, and found that the foliation, instead of being initially transverse, consisted of several arcuate sets, each defining an individual flow unit, merging down-glacier into a single arc system. On the basis of relations with minor structures, he suggested that the foliation is initially parallel to one of the planes of maximum shear stress. This new foliation then rotates with respect to the principal stress directions during progressive strain.

The critical questions seem to be: where in the ice fall and in what attitude does arcuate foliation form? In Griesgletscher it certainly does not develop at the base of the ice fall. Furthermore, the measured strain-rates are incompatible with either the longitudinal compression hypothesis or the shear hypothesis. In particular, the principal strain-rates, and by analogy the stresses, have no specific orientation with respect to the foliation. In part, the structure is normal to the maximum compression, in part at various other angles to it (Fig. 5); it is also strongly developed in parts of the profile where the principal strain-rates (stresses) are very small.

On large-scale aerial photographs of Griesgletscher the foliation can be traced up through the ice fall into the heavily crevassed area near the top, where transverse crevasses are dominant (Fig. 5). When climbing up the ice fall the foliation can easily be followed almost to the

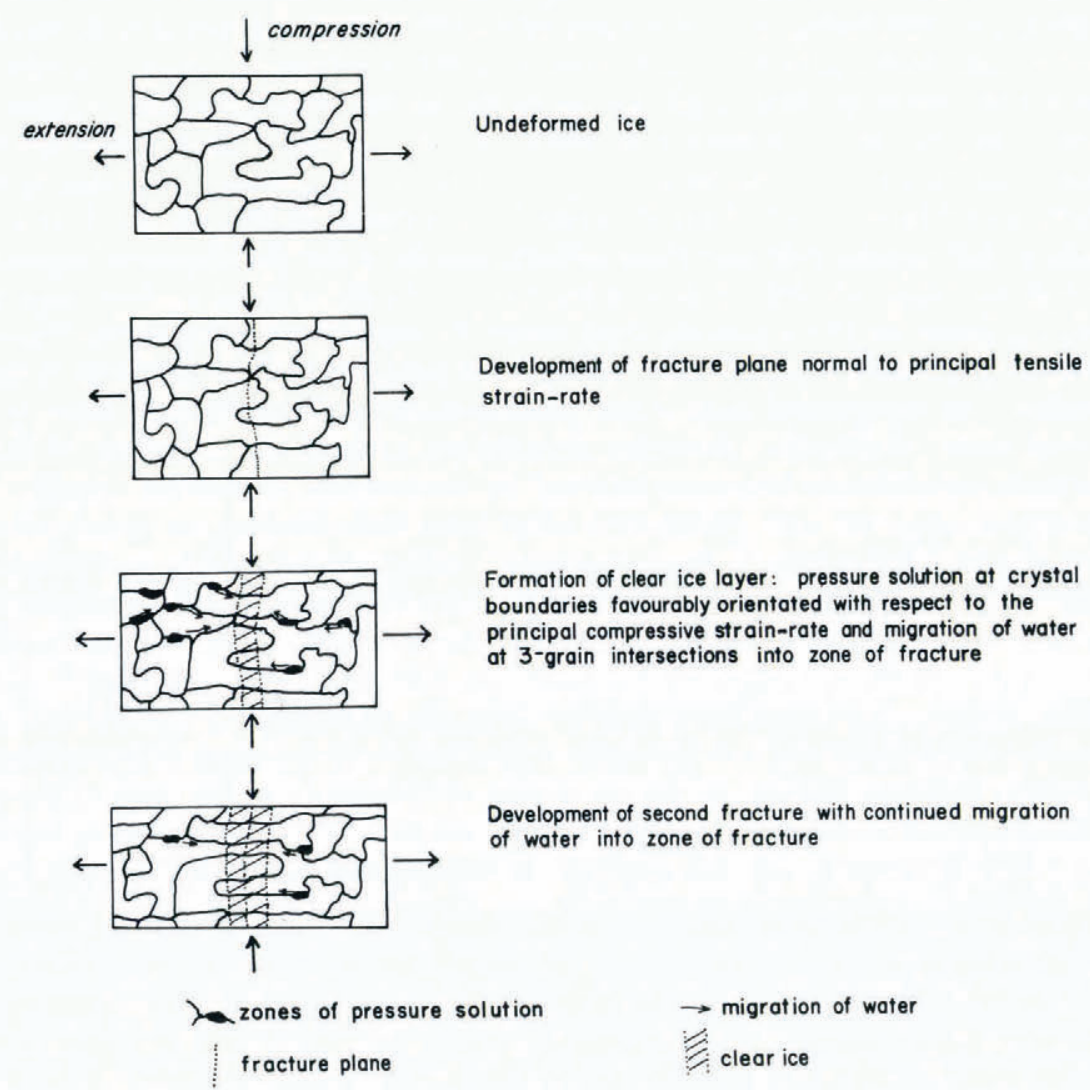

Fig. 7. Schematic diagram illustrating the development of crevasse traces. This represents the development of tensional veins which occur below the depth to which crevasse walls separate, and where surface melt waters may be unable to penetrate. 
top, and it is clear that it remains essentially vertical regardless of slope, as do the crevasses in this area. Near the top, the foliation is crudely parallel to the transverse crevasses, and is itself essentially of transverse orientation, but it becomes arcuate in form within a short distance as it descends the ice fall. Clearly, a relationship exists between arcuate foliation and transverse crevassing in Griesgletscher. We have observed similar relationships even more clearly in several other Alpine glaciers, notably Gornergletscher and its tributaries, and Glacier de Saleina; we also believe that arcuate foliation can develop in many glaciers without ice falls if they have zones of transverse crevassing, for example Oberaargletscher and Vadrec da l'Albigna (Hambrey, I977).

In effect, therefore, the arcuate foliation of Griesgletscher and other glaciers probably develops as a set of crevasse traces, i.e. as coarse clear ice layers parallel to crevasses. The exact mechanism is uncertain but the similarity of these layers to "tectonic veins" such as those of quartz, found in many deformed rock bodies (e.g. Durney and Ramsay, r973), suggests that they develop under tension, as hypothesized earlier (Hambrey and Müller, 1978) and amplified in Figure 7. Their subsequent geometry is a reflection of the strain history soon after formation, particularly within the ice fall, whereas in the tongue this arcuate foliation behaves more or less as a passive marker.

\section{Conclusions}

Although studies of deformation rates, and hence stress, in glaciers are in themselves interesting, they are of little use on their own in trying to establish modes of origin of such secondary structures as foliations. One reason for this is that strain-rates are extremely variable and reflect only small increments of strain, which may be entirely fortuitous at the particular point of measurement. It is more important to consider the strain history of a mass of ice as it moves through the glacier, and in particular how the structures relate to the cumulative strain at different stages of their development.

It is becoming increasingly evident from detailed mapping that many foliations in glaciers are derived from earlier layering, particularly stratification and crevasse traces, sometimes by transposition and sometimes by rotation and re-alignment under conditions of shear or compressive strain. In many cases, it will not be possible to establish whether or not this applies, but at least efforts should be made to trace structures to their source.

\section{Agknowledgements}

We are grateful to the Versuchsanstalt für Wasserbau, Hydrologie und Glaziologie, ETH Zürich, for allowing us to use flow data from Griesgletscher obtained for Kraftwerke Aegina AG; to H. Röthlisberger, M. Aellen, and F. Müller for advice on Swiss glaciers generally; to E. Imstepf for making available accommodation in the barracks close to the glacier; and to friends and students who assisted in the field work. The project was financially supported between 1974 and 1976 by the "Zentenarfonds" of the ETH. We also wish to thank W. H. Theakstone for reviewing a draft of this paper.

MS. received 25 June 1979 and in revised form 21 November 1979 
Note. The numerical data referred to in this paper have been deposited in World Data Centre C, Scott Polar Research Institute, Lensfield Road, Cambridge CB2 IER, England:

Table I. Retreat of the snout of Griesgletscher between 196r and 1976 (data published annually in Die Alpen, the journal of the Swiss Alpine Club).

Table 2. Horizontal components of stake velocities at the surface of Griesgletscher, 1971-72 and $1972-73$.

Table 3. "Regional" strain-rates in $\mathrm{a}^{-1}$ parallel to the surface of Griesgletscher, 1972-73. See Figure ic for the key to strain triangles.

Table 4. "Local" strain-rates in $\mathrm{a}^{-1}$ parallel to the surface of Griesgletscher, 1975-76. 400-404 on a longitudinal profile near the south margin; 500-539 on a transverse profile at the foot of the ice fall.

\section{REFERENCES}

Allen, C. R., and others. 196o. Structure of the lower Blue Glacier, Washington, [by] C. R. Allen, W. B. Kamb, M. F. Meier, and R. P. Sharp. Fournal of Geology, Vol. 68, No. 6, p. 6o1-25.

Anderton, P. W. 1973. Structural glaciology of a glacier confluence, Kaskawulsh Glacier, Yukon Territory, Canada. Ohio State University. Institute of Polar Studies. Report No. 26.

Durney, D. W., and Ramsay, J. G. 1973. Incremental strains measured by syntectonic crystal growths. (In de Jong, K. A., and Scholten, R., ed. Gravity and tectonics. New York, John Wiley and Sons, Inc., p. 67-96.)

Gunn, B. M. 1964. Flow rates and secondary structures of Fox and Franz Josef Glaciers, New Zealand. Journal of Glaciology, Vol. 5, No. 38, p. 173-9o.

Hambrey, M. J. 1976. Structure of the glacier Charles Rabots Bre, Norway. Geological Society of America. Bulletin, Vol. 87, No. I1, p. 1629-37.

Hambrey, M. J. 1977. Structures in ice cliffs at the snouts of three Swiss glaciers. Journal of Glaciology, Vol. 18, No. 8 o, p. $407-14$.

Hambrey, M. J., and Milnes, A. G. 1977. Structural geology of an Alpine glacier (Griesgletscher, Valais, Switzerland). Eclogae Geologicae Helvetiae, Vol. 70, No. 3, p. 667-84.

Hambrey, M. J., and Müller, F.' 1978 . Structures and ice deformation in the White Glacier, Axel Heiberg Island, Northwest Territories, Canada. Fournal of Glaciology, Vol. 20, No. 82, p. 41-66.

Hooke, R. L., and Hudleston, P. J. 1978. Origin of foliation in glaciers. Fournal of Glaciology, Vol. 20, No. 83, p. $285-99$.

Meier, M. F. 196o. Mode of flow of Saskatchewan Glacier, Alberta, Canada. U.S. Geological Survey. Professional Paper 35I.

Meier, M. F., and others. 1974. Flow of Blue Glacier, Olympic Mountains, Washington, U.S.A., by M. F. Meier, W. B. Kamb, C. R. Allen, and R. P. Sharp. Fournal of Glaciology, Vol. 13, No. 68, p. 187-212.

Milnes, A. G., and Hambrey, M. J. 1976 . A method of estimating approximate cumulative strains in glacier ice. Tectonophysics, Vol. 34 , Nos. $3-4$, p. T23-T27.

Ragan, D. M. 1969. Structures at the base of an icefall. Fournal of Geology, Vol. 77, No. 6, p. 647-67.

Rutter, N. W. 1965. Foliation pattern of Gulkana Glacier, Alaska Range, Alaska. Journal of Glaciology, Vol. 5 , No. 4 I, p. $711-18$.

Schwarzacher, W., and Untersteiner, N. 1953. Zum Problem der Bänderung des Gletschereises. Sitzungsberichte der Österreichischen Akademie der Wissenschaften. Mathematisch-naturwissenschaftliche Klasse, Abt. 2A, Bd. I62, Ht. $1-4$, p. I I I -45 . 